\title{
くミニシンポジウム $>$
}

\section{重症急性脳梗塞には t-PA 静注療法より血管内治療が勝る}

\author{
吉井 仁1) 塚越 敬子 ${ }^{1)}$ 八木 俊輔1) 中井 紀嘉1 \\ 鈴木 康弘 ${ }^{1)}$ 过 裕丈 ${ }^{2)}$ 松井 克至 ${ }^{3)}$ 長田 成幸4) \\ 1)静岡済生会総合病院神経内科, $\left.{ }^{2}\right)$ 岐阜社会保険病院神経内科, \\ 3) 春日井市民病院神経内科, ${ }^{4}$ 国立病院機構名古屋医療センター神経内科
}

(脳卒中 $28: 641,2006$ )

【目的】 t-PA 静注療法がようやく日本でも認可され

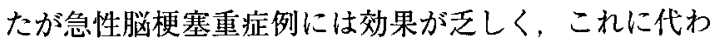
る治療法が求められている. 我々は従来から急性脳梗 塞重症例に血管内治療による血行再開を行ってきた が，ここにその治療成績を報告する.【方法】対象は 1990 年 1 月から 2003 年 12 月までの治療前 NIHSS 20 以上の急性脳梗塞重症例で血行再開（局所線溶. PTA + 局所線溶）を行った 141 例（内頸動脈閉塞 33 例, 中大脳動脈閉塞 80 例, 脳底動脈閉塞 28 例）であ る.【成績】年齢は IC 閉塞 70 歳, MCA 閉塞 69 歳, BA 閉塞 67 歳であり, 治療前 NIHSS は IC 閉塞 26 点, MCA 閉塞 23 点, BA 閉塞 34 点であった. 発症から治 療開始までの時間は IC 閉塞 2.7 時間, MCA 閉塞 2.9 時間. BA 閉塞 3.4 時問であった. TIMI $2+3$ の再開通 は IC 閉塞 $55 \%$, MCA 閉塞 $68 \%$ ，BA 閉塞 $75 \%$ に認 められた. 3 力月後の転帰では $\mathrm{mR} \leqq 1$ の完全自立が
IC 閉塞 24\%, $\mathrm{MCA}$ 閉塞 44\%，BA 閉塞 46\% に得ら れ, $\mathrm{mR} \leqq 2$ の機能的自立では各々 $30 \%, 56 \%, 54 \%$ で あった. 36 時間以内の症候性頭蓋内出血は IC 閉塞 $18 \%, \mathrm{MCA}$ 閉塞 $6 \%, \mathrm{BA}$ 閉塞 0\%に出現し, 死亡率 は各々 45\%，15\%，0\%であった.【結論】我々の成績

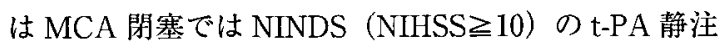
群, PROACT2 の局所線溶群, IMS $の$ t-PA 静注 $+\mathrm{t}-$ $\mathrm{PA}$ 局注群の 3 力月後の転帰, $\mathrm{mR} \leqq 1$ の完全自立 $(32 \%: 26 \%: 30 \%), \mathrm{mR} \leqq 2$ の機能的自立 $(39 \%$ : 40\%：43\%）と比較し優れており，また症候性頭蓋内 出血 $(6.6 \%: 10 \%: 6 \%)$, 死亡率 $(21 \%: 25 \%: 16 \%)$ も 3 群に比較し少なかった. IC 閉塞, BA 閉塞では比 較する対象がないが，IC 閉塞でも死亡率は高いものの $\mathrm{mR} \leqq 10$ 完全自立が $24 \%$ あったことは注目に値す る. 以上より急性脳梗塞重症例では極早期に積極的血 行再開を図ることが肝要である 